\title{
DMSO Molecule as Ancillary Ligand in Ru-Based Catalysts for Ring Opening Metathesis Polymerization
}

\author{
Sirlane A. A. Santana, Valdemiro P. Carvalho Jr. and Benedito S. Lima-Neto* \\ Instituto de Química de São Carlos, Universidade de São Paulo, \\ CP 780, 13560-970 São Carlos-SP, Brazil
}

\begin{abstract}
A polimerização via metátese por abertura de anel (ROMP) de norborneno (NBE) ocorre em presença do complexo $f a c$ - $\left[\mathrm{RuCl}_{2}(\mathrm{~S}-\mathrm{DMSO})_{3}(\mathrm{O}-\mathrm{DMSO})\right]$ e etildiazoacetato $(5 \mu \mathrm{L})$, onde DMSO é dimetilsulfóxido coordenado pelo átomo de enxofre ou de oxigênio. O rendimento é $62 \%$ $(\mathrm{PDI}=1,64)$ à temperatura ambiente por $5 \mathrm{~min}$ e $88 \%(\mathrm{PDI}=1,93)$ a $50^{\circ} \mathrm{C}$ por $30 \mathrm{~min}$, com [NBE]/ $[\mathrm{Ru}]=516 \mathrm{em} \mathrm{CHCl}_{3}$. Na presença de $\mathrm{NBu}_{4} \mathrm{ClO}_{4}$ o rendimento é $90 \%(\mathrm{PDI}=1,64)$ à temperatura ambiente por $5 \mathrm{~min}$. O complexo é praticamente inativo quando uma ou duas moléculas de DMSO são substituídas por piridina, imidazol, 2-metil-imidazol ou benzoimidazol. A formação in situ da espécie catalítica e os comportamentos das moléculas de DMSO como ligantes ancilares nas reatividades dos complexos de $\mathrm{Ru}^{\mathrm{II}}$ são discutidas nesse trabalho.
\end{abstract}

The ring-opening metathesis polymerization (ROMP) of norbornene (NBE) occurs in the presence of the $f a c$ - $\left[\mathrm{RuCl}_{2}(\mathrm{~S}-\mathrm{DMSO})_{3}(\mathrm{O}-\mathrm{DMSO})\right]$ complex and ethyldiazoacetate $(5 \mu \mathrm{L})$, where DMSO is S- or O-bonded dimethylsulfoxide. The yield is $62 \%(\mathrm{PDI}=1.64)$ at room temperature for $5 \mathrm{~min}$ and $88 \%\left(\mathrm{PDI}=1.93\right.$ ) at $50{ }^{\circ} \mathrm{C}$ for $30 \mathrm{~min}$, with $[\mathrm{NBE}] /[\mathrm{Ru}]=516 \mathrm{in} \mathrm{CHCl}_{3}$. The yield is $90 \%$ (PDI = 1.64) in the presence of $\mathrm{NBu}_{4} \mathrm{ClO}_{4}$ at room temperature for $5 \mathrm{~min}$. The complex is practically inactive when one or two molecules of DMSO are replaced by pyridine, imidazole, 2-methyl-imidazole or benzimidazole. The in situ formation of the catalytic species and the behavior of the DMSO molecules as ancillary ligands in the reactivity of the $\mathrm{Ru}^{\mathrm{II}}$ complexes are discussed.

Kewords: olefin metathesis, ROMP, ancillary ligand, ruthenium, DMSO

\section{Introduction}

Over the last 15 years, olefin metathesis has been widely applied in organic and polymer synthesis. ${ }^{1-5}$

The significance of this process for so many purposes was recognized by The Nobel Foundation and the researchers, Yves Chauvin (Institut Francais du Petrole, France), Robert H. Grubbs (California Institute of Technology, USA) and Richard R. Schrock (Massachusetts Institute of Technology, USA) were awarded the Nobel Prize for Chemistry in 2005 "for the development of the metathesis method in organic synthesis". ${ }^{6}$ Grubbs and Schrock develop well-defined metal-carbene catalysts for the reaction, following the mechanistic proposal suggested

*e-mail: benedito@iqsc.usp.br by Chauvin. Whereas Grubbs mainly works with $\mathrm{Ru}$, Schrock mainly works with Mo and W.

Ru-based compounds are user-friendly catalysts for many olefin metathesis processes because they are resistant towards many basic functional groups. ${ }^{1-3,5,7}$

Besides the self-electronic nature of the metal center in the metal-carbene complex, the electronic and steric effects of the ancillary ligands can provide catalysts which are able to promote high-efficiency alkene metathesis. ${ }^{1,2,6,7}$ Typically, phosphines, esters, amines and N-heterocyclic carbenes have been tested as ancillary ligands.

Thus, the combination of metal and ligands can provide powerful catalysts for olefin metathesis.

While the novel Grubbs and Schrock carbene-type catalysts are well established, there is a claim for cheaper and more robust industrial type catalysts considering large-scale applications. ${ }^{2,7-9}$ For this type of procedure, 
the carbene catalyst would be generated in-situ from precatalysts used as starting compounds.

The development of precatalysts is also based on the influence of the ancillary ligands on the metal center as occurs in the cases with metal-carbene catalysts. An important key in the use of non-carbene type catalysts as starting compounds is the beginning metal reactivity considering the in-situ formation of the catalyst itself.

With this in mind, we have worked to discover new $\mathrm{Ru}^{\mathrm{II}}$-based precatalysts for ring-opening metathesis polymerization (ROMP) of cyclic olefins (Scheme 1), with the purpose of establishing strategies for syntheses of precatalyst compounds capable of working in mild conditions of temperature and resistant to air (meaning $\mathrm{O}_{2}$ ) and moisture, which would be cheaper for industrial processes. ${ }^{10}$ In addition, these compounds could be stored and handled without large restriction to air, moisture, light and warmth, which are typical tropical conditions.

The fac $\left[\mathrm{RuCl}_{2}(\mathrm{~S}-\mathrm{DMSO})_{3}(\mathrm{O}-\mathrm{DMSO})\right]$ complex is neither atmospheric air nor moisture sensitive and easy to handle and fulfill the requirements discussed above. ${ }^{11,12}$

In general, an interesting feature of sulfoxide molecules is the ambidentate nature. ${ }^{13}$ Both metal-S-bonded and metalO-bonded complexes are isolated with dimethylsulfoxide (DMSO) as a ligand. ${ }^{13}$ The linkage isomers with S- and O-bonded complexes depend on the oxidation state of the metal and the electronic and steric properties of the sulfoxide, as well as the other coordinated ligands. ${ }^{13}$ The metal-S-bonded mode is usual with "soft" metal centers, such as low spin $\mathrm{d}^{6} \mathrm{Ru}^{\mathrm{II}}$ complexes, where $\mathrm{d}_{\pi}$ back-bonding is observed. ${ }^{13}$
In $f a c-\left[\mathrm{RuCl}_{2}(\mathrm{~S}-\mathrm{DMSO})_{3}(\mathrm{O}-\mathrm{DMSO})\right]$, the O-DMSO molecule is axial and it is more labile than the other S-bonded ligands. ${ }^{13}$ This complex experiences an easy ligand substitution reaction and is a starting material for new complexes with phosphine, $\mathrm{CO}, \mathrm{NO}$ and amine ligands, for example. ${ }^{12,13}$

The complex $f a c-\left[\mathrm{RuCl}_{2}(\mathrm{~S}-\mathrm{DMSO})_{3}(\mathrm{O}-\mathrm{DMSO})\right]$ was evaluated as a catalyst precursor for 1-hexene hydrogenation with successful results. ${ }^{14}$ It is well known that in this type of process at least two labile positions are necessary to make the reaction happen, as for olefin metathesis (Scheme 1). Thus, this complex with DMSO can be an alternative catalyst for ROMP application under mild conditions, where the DMSO molecules would be ancillary ligands. In addition, this complex can be an alternative to the ill-defined $\mathrm{Ru}^{\mathrm{III}}$ salts employed in industry ${ }^{9}$ as it behaves as a well-defined $\mathrm{Ru}^{\mathrm{II}}$ coordination complex. Indeed, the DMSO molecule was already tested in the Ru-based ROMP precatalyst where the $f a c$ - $\left[\mathrm{RuCl}_{2}(\mathrm{~S}-\mathrm{DMSO})_{3}(\mathrm{O}-\right.$ $\mathrm{DMSO})$ ] complex was a precursor for the syntheses of $\mathrm{Ru}-$ allenylidene complexes of type $\left[\mathrm{RuCl}_{2}\left(=\mathrm{C}=\mathrm{C}=\mathrm{CR}_{2}\right)\left(\mathrm{PCy}_{3}\right)_{\mathrm{n}}\right.$ $\left.(\mathrm{DMSO})_{\mathrm{m}}\right]$ and $\left.\mathrm{RuCl}\left(=\mathrm{C}=\mathrm{C}=\mathrm{CR}_{2}\right)\left(\mathrm{PCy}_{3}\right)_{\mathrm{n}}(\mathrm{DMSO})_{\mathrm{m}}\right]$ (triflate).$^{15}$ However, the article did not mention the role of DMSO in the reactivity of the complexes.

In this work, considering that in the course of our research with $\mathrm{Ru}^{\mathrm{II}}$ complexes, we found a beneficial effect of the combination of usual amines and phosphines as ancillary ligands, ${ }^{10}$ the activities of the complexes $f a c-\left[\mathrm{RuCl}_{2}(\mathrm{~S}\right.$ $\left.\mathrm{DMSO})_{3}(\mathrm{O}-\mathrm{DMSO})\right]$ and $\left[\mathrm{RuCl}_{2}(\mathrm{~S}-\mathrm{DMSO})_{4-\mathrm{x}}(\mathrm{N})_{\mathrm{x}}\right]$ derivatives were investigated for ROMP of norbornene (NBE), where $\mathrm{N}=$ pyridine, imidazole, benzimidazole

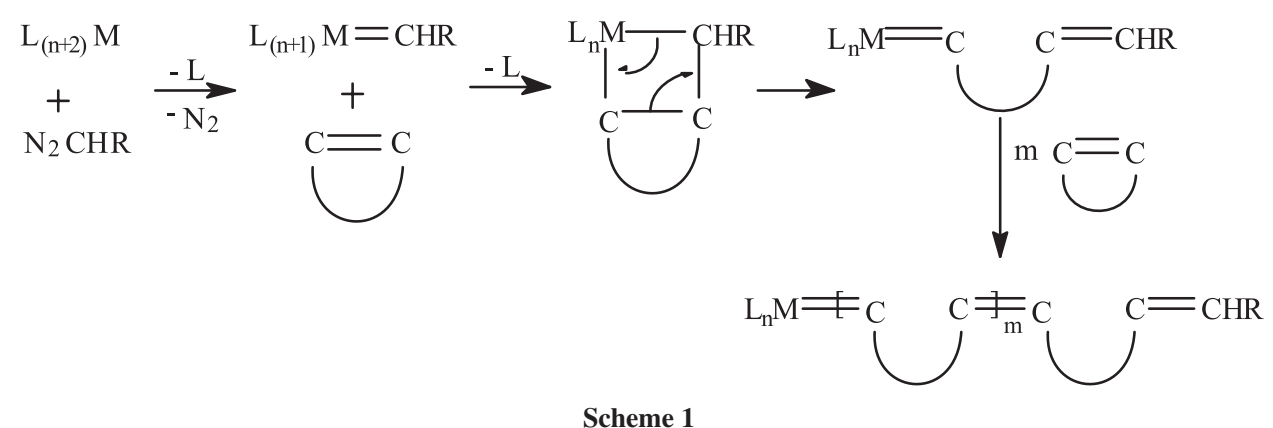<smiles>c1ccncc1</smiles><smiles>c1c[nH]cn1</smiles>

pyridine (py) $\mathrm{pK}_{\mathrm{a}} 5.2$ $\theta=91.2^{\circ}$ imidazole (im) $\mathrm{pK}_{\mathrm{a}} 6.9$ $\theta=82.9^{\circ}$
Scheme 1<smiles>c1ccc2[nH]cnc2c1</smiles><smiles>Cc1ncc[nH]1</smiles>

benzimidazole (bzim) $\mathrm{pK}_{\mathrm{a}} 5.3$

2-methyl-imidazole (Meim) $\mathrm{pK}_{\mathrm{a}} 7.8$ 
or 2-methyl-imidazole (Scheme 2). In these complexes there are also combinations of $\sigma$-donor and $\pi$-receptor ligands. Different reactant concentrations, reaction time and temperature were examined, using ethyldiazoacetate (EDA) as a starting source of carbene. The formation of the in situ active catalytic species was discussed in each case, emphasizing the behavior of the DMSO molecule as an ancillary ligand.

\section{Experimental}

\section{General remarks}

All the handling was carried out under argon atmosphere. Ruthenium trichloride, $\mathrm{NBu}_{4} \mathrm{ClO}_{4}$, pyridine (py), imidazole (im), 2-methyl-imidazole (Meim), benzimidazole (bzim) and ethyldiazoacetate (EDA; $\mathrm{N}_{2} \mathrm{CHCOOCH}_{2} \mathrm{CH}_{3}$ ) from Aldrich, norbornene (NBE) from Across and silver triflate from Strem were used without further purification. Analytical grade solvents were freshly distilled prior to use. CHN analyses were performed on an EA 1110 CHNS-O Carlo Erba Instrument. IR spectra were obtained on a BOMEM FTIR MB 102 SERIES spectrometer with samples dispersed in CsI pellets or $0.1 \mathrm{~mm}$ liquid cell ( $\mathrm{NaCl}$ windows). ${ }^{1} \mathrm{H} \mathrm{NMR}$ spectra were recorded on a Bruker AC 200 spectrometer $\left(\mathrm{CDCl}_{3}\right)$. All spectra were run at room temperature $(\mathrm{RT})$ with residual proton as an internal standard. Electronic spectra were obtained in a quartz cell $(1.00 \mathrm{~cm})$ on a Lambda 40 Perkin-Elmer UV-Vis spectrophotometer equipped with a Pettier thermostat. The molecular weights $\left(\mathrm{M}_{\mathrm{w}} ; \mathrm{M}_{\mathrm{n}}\right)$ and the polydispersity index $\left(\mathrm{PDI}=\mathrm{M}_{\mathrm{w}} / \mathrm{M}_{\mathrm{n}}\right.$ ) of the polymers were determined by gel permeation chromatography at room temperature using a Shimadzu 77251 system equipped with two serial placed columns (PLgel $5 \mu \mathrm{m}$ MIXED-C: $30 \mathrm{~cm}$, $\varnothing=7.5 \mathrm{~mm}$ ). The retention times were calibrated with standard monodispersed polystyrene using HPLC-grade $\mathrm{CHCl}_{3}$ as an eluent.

\section{Syntheses of the complexes}

The complexes were prepared according to the literature procedures: $f a c$ - $\left[\mathrm{RuCl}_{2}(\mathrm{~S}-\mathrm{DMSO})_{3}(\mathrm{O}-\mathrm{DMSO})\right]$ (Anal. Calc.: C, 19.83, H, 4.99; Found: C, 19.80, H, 4.79\%); fac-[ $\left.\mathrm{RuCl}_{2}(\mathrm{~S}-\mathrm{DMSO})_{3}(\mathrm{py})\right]$ (Anal. Calc.: C, 27.21; H, 4.77; N, 2.88; Found: C, 27.09; H, 4.81; N, 2.70\%); fac$\left[\mathrm{RuCl}_{2}(\mathrm{~S}-\mathrm{DMSO})_{3}(\mathrm{im})\right]$ (Anal. Calc.: C, 22.79; H, 4.68; N, 5.91; Found: C, 22.85; H, 4.32; N, 6.23\%); cis, cis,cis$\left[\mathrm{RuCl}_{2}(\mathrm{~S}-\mathrm{DMSO})_{2}(\mathrm{im})_{2}\right]$ (Anal. Calc.: C, 25.86; H, 4.34; N, 12.06; Found: C, 26.15; H, 4.24; N, 11.94\%); cis, cis, cis$\left[\mathrm{RuCl}_{2}(\mathrm{~S}-\mathrm{DMSO})_{2}(\mathrm{Meim})_{2}\right]$ (Anal. Calc.: C, 29.79; H, 4.91; N, 11.38; Found: C, 29.36; H, 4.44; N, 11.41\%); cis,cis, cis-
$\left[\mathrm{RuCl}_{2}(\mathrm{~S}-\mathrm{DMSO})_{2}\left(\right.\right.$ bzim) $\left.{ }_{2}\right]$ (Anal. Calc.: C, 38.30; H, 4.25; N, 9.92. Found: C, 38.72; H, 4.23; N, 9.99\%). ${ }^{16}$

\section{Polymerization procedures}

In a typical experiment with $f a c$ - $\left[\mathrm{RuCl}_{2}(\mathrm{~S}-\mathrm{DMSO})_{3}(\mathrm{O}-\right.$ DMSO)], $100 \mathrm{mg}$ of NBE (1.2 mmol) and $5 \mu \mathrm{L}$ of EDA $(5.4 \mu \mathrm{mol})$ were added to a solution of the complex $(2.1 \mu \mathrm{mol})$ in $\mathrm{CHCl}_{3}(2.5 \mathrm{~mL})$. The reaction mixture was maintained at room temperature (RT; $24 \pm 1{ }^{\circ} \mathrm{C}$ ) or $50{ }^{\circ} \mathrm{C}$ (silicone oil bath; $\pm 1^{\circ} \mathrm{C}$ ) for $5 \mathrm{~min}$. Methanol was added to the cooled solution and the precipitated polymer was filtered, washed with methanol and dried under ambient conditions. The polymerization yields were determined gravimetrically. The catalytic runs were repeated at least 3-6 times. Errors associated with weighting of NBE or isolating and drying the polymer explain the variations in yields. The polymer was not produced when the reaction was carried out in absence of Ru complex either at RT or $50{ }^{\circ} \mathrm{C}$ for $90 \mathrm{~min}$.

In experiments as a function of time, the reactions were quenched with methanol. In experiments as a function of the EDA molar ratio, the reactions were initiated with different volumes of EDA, maintaining both the complex and NBE concentrations constant. In experiments as a function of $[\mathrm{NBE}] /[\mathrm{Ru}]$ molar ratio, different weights of monomer were used in order to maintain the complex concentration constant.

Polymerization reactions in the presence of excess $\mathrm{NBu}_{4} \mathrm{ClO}_{4}, \mathrm{NaCl}$, DMSO or amines were carried out with $100 \mu \mathrm{mol}$ of each compound added to the complex solutions $\left(2.1 \mu \mathrm{mol}\right.$ in $\left.2.5 \mathrm{~mL} \mathrm{CHCl}_{3}\right)$. The mixtures were stirred at RT for $30 \mathrm{~min}$. Then, typical polymerization procedures were carried out.

Substitution reaction of $\mathrm{Cl}^{-}$ion by triflate ion was obtained with a fresh Ru solution $(2.1 \mu \mathrm{mol}$ in $2.5 \mathrm{~mL}$ $\mathrm{CHCl}_{3}$ ) in the presence of $2 \mu \mathrm{mol}$ of $\mathrm{AgCF}_{3} \mathrm{SO}_{3}$ at RT for $10 \mathrm{~min}$. The produced $\mathrm{AgCl}$ was filtered off and the resulting solution was used for polymerization tests.

\section{Results and Discussion}

\section{Catalytic experiments}

In order to propose a route and the cause for ROMP of NBE with the Ru-DMSO complexes, a number of reactions were carried out.

The results as a function of EDA volume and [NBE]/ $[\mathrm{Ru}]$ molar ratio at RT with $f a c-\left[\mathrm{RuCl}_{2}(\mathrm{~S}-\mathrm{DMSO})_{3}(\mathrm{O}-\right.$ DMSO)] as starting material are summarized in Table 1.

Whereas the polymerization reaction did not occur in the absence of EDA at RT for 90 min (Table 1; entry 1), 
Table 1. Influence of EDA volume, $[\mathrm{NBE}] /[\mathrm{Ru}]$ molar ratio and reaction time on the ROMP of NBE with $f a c-\left[\mathrm{RuCl}_{2}(\mathrm{~S}-\mathrm{DMSO})_{3}(\mathrm{O}-\mathrm{DMSO})\right]$ at $\mathrm{RT}$

\begin{tabular}{|c|c|c|c|c|c|}
\hline Entry & EDA volume / $\mu \mathrm{L}(\mu \mathrm{mol})$ & {$[\mathrm{NBE}] /[\mathrm{Ru}]$} & time / min & Yield / \% & trans-content / \% \\
\hline 1 & 0 & 516 & 5 & 0 & \\
\hline 2 & $1(9.5)$ & 516 & 5 & $21 \pm 3$ & \\
\hline 3 & $2(19)$ & 516 & 5 & $44 \pm 4$ & \\
\hline 4 & $3(28.5)$ & 516 & 5 & $51 \pm 3$ & 56 \\
\hline 5 & $4(38)$ & 516 & 5 & $54 \pm 3$ & 56 \\
\hline 6 & $5(47.5)$ & 516 & 5 & $62 \pm 6$ & 61 \\
\hline 7 & $10(95)$ & 516 & 5 & $58 \pm 8$ & 53 \\
\hline 8 & $15(143)$ & 516 & 5 & $59 \pm 4$ & 56 \\
\hline 9 & $20(190)$ & 516 & 5 & $53 \pm 4$ & 54 \\
\hline 10 & 5 & 1031 & 5 & $71 \pm 2$ & 57 \\
\hline 11 & 5 & 1547 & 5 & $73 \pm 8$ & 56 \\
\hline 12 & 5 & 2062 & 5 & $78 \pm 4$ & 56 \\
\hline 13 & 5 & 2578 & 5 & $79 \pm 8$ & 56 \\
\hline 14 & 5 & 3094 & 5 & $83 \pm 1$ & 52 \\
\hline 15 & 5 & 5156 & 5 & $81 \pm 3$ & 50 \\
\hline 16 & 5 & 516 & 10 & $60 \pm 7$ & 51 \\
\hline 17 & 5 & 516 & 20 & $68 \pm 6$ & 52 \\
\hline 18 & 5 & 516 & 30 & $71 \pm 7$ & 53 \\
\hline 19 & 5 & 516 & 60 & $80 \pm 6$ & 55 \\
\hline 20 & 5 & 516 & 120 & $83 \pm 7$ & 57 \\
\hline
\end{tabular}

$2.1 \mu \mathrm{mol}$ of $\mathrm{Ru}$ in $2.5 \mathrm{~mL}$ of $\mathrm{CHCl}_{3}$.

polymers were isolated when the reactions were carried out in the presence of EDA at RT for 5 min (Table 1; entries 2-9). Similar behavior was observed for $[\mathrm{RuCl}(\mu-\mathrm{Cl})$ $\left.\left(\eta^{3}: \eta^{3}-\mathrm{C}_{10} \mathrm{H}_{16}\right)\right]_{2}$ when $2 \mu \mathrm{L}$ of EDA were necessary to initiate the reaction with $\mathrm{NBE} \cdot{ }^{17}$ In the present case, the dependence of the yield on the EDA volume becomes relatively constant over $5 \mu \mathrm{L}$ with $c a$. $60 \%$ yield, as suggested from the saturation profile observed in the plot of reaction yield versus EDA volume (Figure 1). This behavior is different from early experiments with fivecoordinated $\left[\mathrm{RuCl}_{2}\left(\mathrm{PPh}_{3}\right)_{2}\right.$ (amine) $)$ complexes where the reactivity decreased with 5-7 $\mu \mathrm{L}$ of EDA. ${ }^{15}$ The difference is associated to excessive coordination of EDA molecules in the case of the five-coordinated complexes, inhibiting the formation of the catalysts. In the present case, where the complex is six-coordinated, a substitution reaction via a dissociative nature mechanism is expected to occur.

The dependence of the yield on the $[\mathrm{NBE}] /[\mathrm{Ru}]$ molar ratio with $5 \mu \mathrm{L}$ of EDA increased up to the value of 3,000 with $c a$. 80\% yield at RT for 5 min (Table 1; entries 6 and 10-15). The polymerization behavior also showed a saturation mechanism profile (Figure 1). The increase in the activity when increases $[\mathrm{NBE}] /[\mathrm{Ru}]$ ration is in agreement with the fact that the most favorable conditions for a

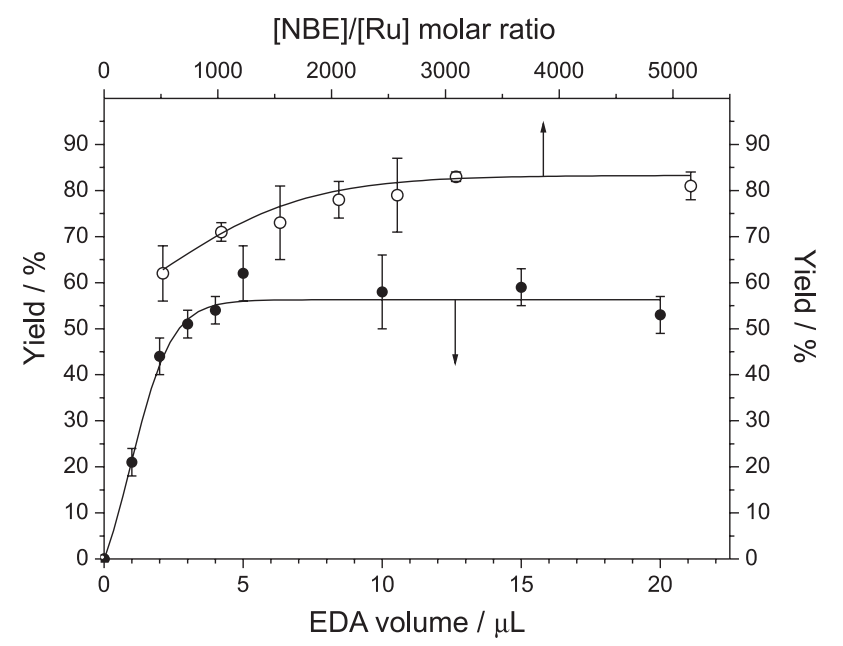

Figure 1. Plots of yields for ROMP of NBE with $c i s-\left[\mathrm{RuCl}_{2}(\mathrm{~S}-\mathrm{DMSO})_{3}(\mathrm{O}-\right.$ DMSO $)]$ versus $\mathrm{EDA}$ volume $([\mathrm{NBE}] /[\mathrm{Ru}]=516)$ and $[\mathrm{NBE}] /[\mathrm{Ru}]$ molar ratio ( $5 \mu \mathrm{L}$ of EDA) at RT for $5 \mathrm{~min} ; 2.1 \mu \mathrm{mol}$ of $\mathrm{Ru}$ in $\mathrm{CHCl}_{3}$.

successful ROMP reaction is to use the highest monomer concentration at the lowest temperature possible in order to decrease the entropic penalty. ${ }^{1}$

Experiments as a function of time and temperature with $5 \mu \mathrm{L}$ of EDA and $[\mathrm{NBE}] /[\mathrm{Ru}]=516$ are shown in Tables 1 and 2. Whereas the reaction yield rose over $80 \%$ when 
Table 2. Influence of temperature and reaction time on the $\mathrm{ROMP}$ of $\mathrm{NBE}$ with $\left[\mathrm{RuCl}_{2}(\mathrm{~S}-\mathrm{DMSO})_{x}(\mathrm{~L})_{y}\right]$ type complexes in absence or presence of $\mathrm{NBu}_{4} \mathrm{ClO}{ }_{4}$

\begin{tabular}{|c|c|c|c|c|c|c|c|c|}
\hline Entry & L ligand (x;y) & $\begin{array}{c}\mathrm{NBu}_{4} \mathrm{ClO}_{4} \\
146 \mu \mathrm{mol}\end{array}$ & $\mathrm{T} /{ }^{\circ} \mathrm{C}$ & time / min & Yield / \% & $\begin{array}{c}\text { trans-content / } \\
\%\end{array}$ & $\mathrm{M}_{\mathrm{w}}\left(\times 10^{4}\right)$ & PDI \\
\hline 1 & O-DMSO $(3 ; 1)$ & absent & RT & 5 & $62 \pm 6$ & 61 & 14 & 1.64 \\
\hline 2 & & absent & 50 & 5 & $65 \pm 4$ & 62 & 9.3 & 1.70 \\
\hline 3 & & absent & 50 & 30 & $88 \pm 9$ & 60 & 9.1 & 1.93 \\
\hline 4 & & present & RT & 5 & $90 \pm 8$ & 56 & 11 & 1.64 \\
\hline 5 & & present & 50 & 30 & $94 \pm 4$ & 63 & 8.9 & 2.12 \\
\hline 6 & py $(3 ; 1)$ & absent & RT & 5 & $8 \pm 1$ & 59 & & \\
\hline 7 & & absent & 50 & 5 & $63 \pm 6$ & 59 & 8.4 & 1.68 \\
\hline 8 & & absent & 50 & 30 & $62 \pm 4$ & 58 & 8.0 & 1.74 \\
\hline 9 & & present & RT & 5 & $8 \pm 2$ & & & \\
\hline 10 & & present & 50 & 30 & $60 \pm 1$ & 59 & 6.1 & 1.85 \\
\hline 11 & $\operatorname{im}(3 ; 1)$ & absent & RT & 5 & $<1$ & & & \\
\hline 12 & & absent & 50 & 5 & $<1$ & & & \\
\hline 13 & & absent & 50 & 30 & $8 \pm 3$ & & & \\
\hline 14 & & present & RT & 5 & 0 & & & \\
\hline 15 & $\operatorname{im}(2 ; 2)$ & absent & RT & 5 & 0 & & & \\
\hline 16 & & absent & 50 & 5 & $<1$ & & & \\
\hline 17 & & absent & 50 & 30 & $<1$ & & & \\
\hline 18 & & present & RT & 5 & 0 & & & \\
\hline 19 & Meim $(2 ; 2)$ & absent & RT & 5 & $<1$ & & & \\
\hline 20 & & absent & 50 & 5 & $<1$ & & & \\
\hline 21 & & absent & 50 & 30 & 42 & 45 & & \\
\hline 22 & & present & RT & 5 & 0 & & & \\
\hline 23 & bzim $(2 ; 2)^{*}$ & absent & RT & 5 & 0 & & & \\
\hline 24 & & absent & 50 & 5 & $<1$ & & & \\
\hline 25 & & absent & 50 & 30 & 5 & & & \\
\hline 26 & & present & RT & 5 & 0 & & & \\
\hline
\end{tabular}

$1 \mathrm{mg}$ of Ru (ca. $2 \mu \mathrm{mol})$ in $2.5 \mathrm{~mL} \mathrm{CHCl}_{3} ; 1.2 \mathrm{mmol}$ of $\mathrm{NBE}([\mathrm{NBE}] /[\mathrm{Ru}]$ ca. 500$) ; 5 \mu \mathrm{L}$ of EDA; *10\% DMF/CHCl . .

increasing the reaction time up to $60 \mathrm{~min}$ at RT (Table 1; entries 6 and 16-20; Figure 2), the yields were similar (62-65\%) either at RT or $50{ }^{\circ} \mathrm{C}$ for $5 \mathrm{~min}$ (Table 2; entries 1-2). However, an almost quantitative conversion at $50{ }^{\circ} \mathrm{C}$ for 30 min was observed (Table 2; entry 3 ).

The Ru catalytic activity is inhibited when in the presence of DMSO (RT for $5 \mathrm{~min} ; 5 \mu \mathrm{L}$ EDA), but it is roughly the same in the presence of $\mathrm{Cl}^{-}$ions with $55 \%$ yield. These experiments support the fact that the $\mathrm{Cl}^{-}$ligands are not involved in the replacement process of ligands for the in situ formation of the catalyst, contrary to DMSO. In addition, this could suggest a participation of $\mathrm{Cl}^{-}$ligands in the reactivity of the catalyst. A proof of this is that the ROMP reaction does not occur under similar conditions when the $\mathrm{Cl}^{-}$ions are replaced by triflate in the starting Ru-DMSO complex. A different behavior was observed for $\left[\mathrm{Ru}(=\mathrm{CPh})\left(\mathrm{OC}_{6} \mathrm{~F}_{5}\right)_{2}(\mathrm{py})\right.$ (IMes)] which occurs in the absence of halide. ${ }^{18}$

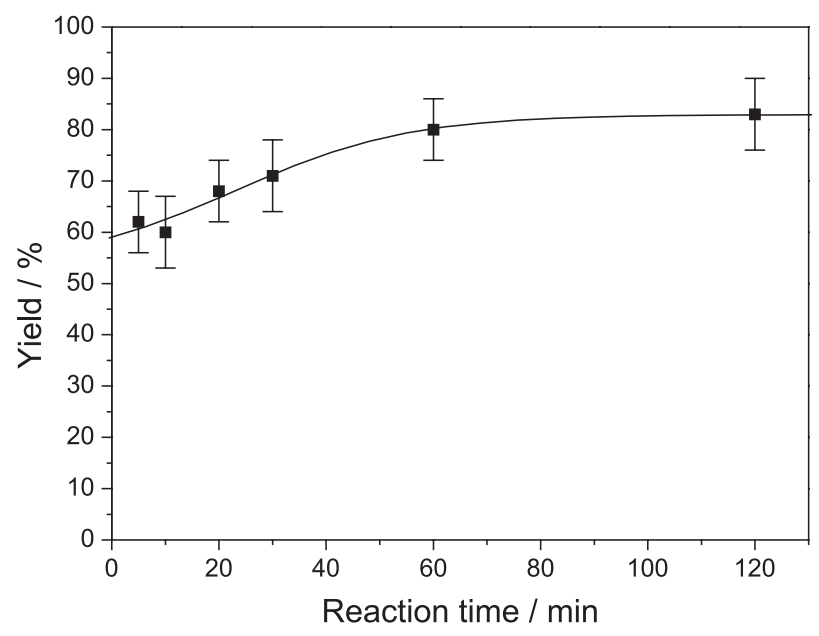

Figure 2. Plot of yield for ROMP of NBE with $c i s-\left[\mathrm{RuCl}_{2}(\mathrm{~S}-\mathrm{DMSO})_{2}(\mathrm{O}-\right.$ DMSO)] versus reaction time at $\mathrm{RT}$ for $5 \mathrm{~min} ; 5 \mu \mathrm{L}$ of EDA, [NBE]/[Ru] = $516,2.1 \mu \mathrm{mol}$ of $\mathrm{Ru}$ in $\mathrm{CHCl}_{3}$. 
The experiments as a function of initial reactant concentrations, time and temperature and in the presence either of $\mathrm{DMSO}$ or $\mathrm{Cl}^{-}$ion suggest that the catalyst formation is kinetically dependent on the DMSO labilization. Thus, in an attempt to accelerate this step, some experiments were carried out in the presence of $\mathrm{NBu}_{4} \mathrm{ClO}_{4}$, as a promoter, considering that the DMSO molecule could be associated with cations in solution and to weaken some Ru-DMSO bonds. ${ }^{13,19}$ The result was $90 \%$ yield in the presence of $\mathrm{NBu}_{4} \mathrm{ClO}_{4}$ at $\mathrm{RT}$ for $5 \mathrm{~min}$ (Table 2; entry 4), which is $c a$. $50 \%$ higher than in the absence of salt. A similar result was observed at $50{ }^{\circ} \mathrm{C}$ for $30 \mathrm{~min}$ (Table 2; entry 5). Hence, this confirms the idea to improve the complex reactivity where there are probable interactions between DMSO and $\mathrm{NBu}_{4} \mathrm{ClO}_{4}$.

On the other hand, in most of the cases, the amounts of isolated polymer were very low when the reactions were carried out with amine derivative complexes either at RT or $50^{\circ} \mathrm{C}$ for 5 or $30 \mathrm{~min}$, even in the presence of $\mathrm{NBu}_{4} \mathrm{ClO}_{4}$ (Table 2). Better results (ca.60\%) were obtained in the case of the complex with pyridine at $50^{\circ} \mathrm{C}$ either for 5 or 30 min (Table 2). However, the reactions were inhibited in the presence of pyridine or DMSO, or replacing the $\mathrm{Cl}^{-}$by triflate ions, at $50{ }^{\circ} \mathrm{C}$ for $30 \mathrm{~min}$. The activities were maintained in the presence of $\mathrm{Cl}^{-}$ions under similar conditions. Then, these results suggest that the py and DMSO molecules leave the metal coordination sphere so that the ROMP can take place. In the case with Meim, the reaction occurs with $42 \%$ of isolated polymer at $50{ }^{\circ} \mathrm{C}$ for 30 min and $\mathrm{NBu}_{4} \mathrm{ClO}_{4}$ does not change the results.

Experiments carried out under air at RT for $5 \mathrm{~min}$ resulted in similar yields (59\%). This is in accordance with the expectation that the complex is quite stable towards air during the catalytic process.

When performing the ROMP reaction with a Ru-DMSO complex solution aged for $24 \mathrm{~h}$ at RT under argon, a similar activity as a fresh solution was obtained with $55 \%$ yield at RT for $5 \mathrm{~min}$, demonstrating stability of the complex in $\mathrm{CHCl}_{3}$.

The GPC data shows $\mathrm{M}_{\mathrm{w}}$ values of $c a \cdot 10^{5}$ and PDI values of 1.6-1.7 for the polyNBEs obtained with $\mathrm{fac}$ $\left[\mathrm{RuCl}_{2}(\mathrm{~S}-\mathrm{DMSO})_{3}(\mathrm{O}-\mathrm{DMSO})\right]$ either in the absence or presence of $\mathrm{NBu}_{4} \mathrm{ClO}_{4}$ with $[\mathrm{NBE}] /[\mathrm{Ru}]=516$ and $5 \mu \mathrm{L}$ of EDA (Table 2). When the temperature is increased to $50{ }^{\circ} \mathrm{C}$, the PDI values are $c a$. 2. This can be attributed to an increased production of the Ru-carbene species in the initiation reaction because of the higher temperature. However, some degree of intermolecular chain-transfer reaction cannot be ruled out, considering the increase in the yield followed by a rise in the molecular weight distribution without increasing the $M_{n}{ }^{1,20}$
The results from ${ }^{1} \mathrm{H}$ NMR pointed out polymers with 51-61\% content in the trans form (Tables 1 and 2).

\section{Mechanism considerations}

The replacement of two adjacent ligands from the $\mathrm{Ru}$ coordination sphere is expected as the present complexes are six-coordinated. Thus, substitution reactions with EDA and NBE must occur to obtain success in the metathesis polymerization.

The electronic spectrum of the $f a c-\left[\mathrm{RuCl}_{2}(\mathrm{~S}-\mathrm{DMSO})_{3}(\mathrm{O}-\right.$ DMSO)] complex in $\mathrm{CHCl}_{3}$ does not change for $48 \mathrm{~h}$ at RT in the absence or presence of NBE (Figure 3). This suggests that the complex does not undergo dissociation of coordinated ligands and it does not react with NBE in the absence of EDA. A different electronic spectrum is immediately observed when adding EDA to the fresh $\mathrm{Ru}$ solution in the absence and presence of NBE. The change is very fast when NBE is present and the solution becomes viscous, consequently suggesting the occurrence of a polymerization process. It is possible to infer that the catalysis process initiates through the formation of the carbene-complex from EDA, followed by a reaction with NBE.

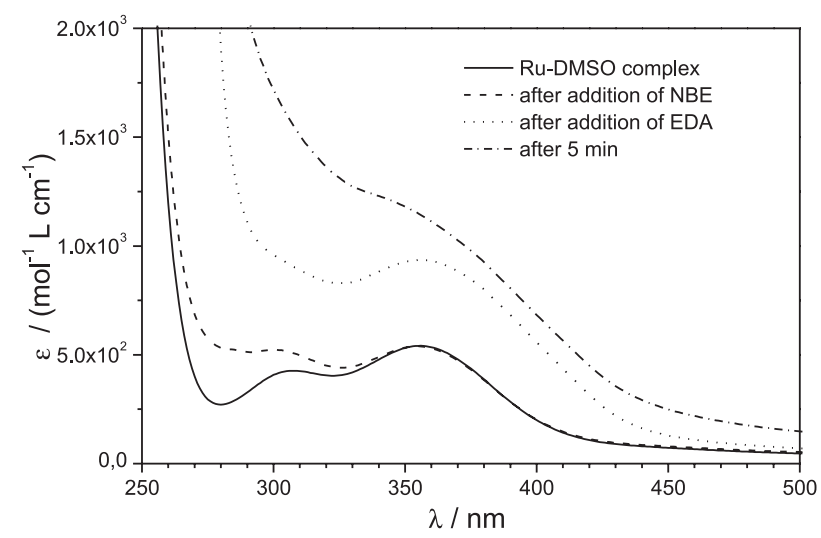

Figure 3. UV-Visible spectra of $c i s-\left[\mathrm{RuCl}_{2}(\mathrm{~S}-\mathrm{DMSO})_{3}(\mathrm{O}-\mathrm{DMSO})\right]$ upon addition of NBE and EDA; $[\mathrm{Ru}]=0.80 \mathrm{mmol} \mathrm{L}^{-1}$ in $\mathrm{CHCl}_{3}$ at $\mathrm{RT}$.

The ${ }^{1} \mathrm{H}$ NMR spectrum of the $\left[\mathrm{RuCl}_{2}(\mathrm{~S}-\mathrm{DMSO})_{3}(\mathrm{O}-\right.$ DMSO)] complex after reacting with EDA showed an increase in the signal at $2.57 \mathrm{ppm}$, attributed to the hydrogen atoms of the methyl group in the free DMSO.$^{21} \mathrm{~A}$ signal at $2.68 \mathrm{ppm}$, attributed to protons from the O-DMSO molecule, does not change. It is known that the axial O-DMSO ligand undergoes an easy replacement because of the soft chemical behavior of the $\mathrm{Ru}^{\mathrm{II}}$ ion. ${ }^{12,13}$ This can provide the formation of the carbene complex in this coordination position, justifying the presence of the free DMSO in solution. In addition, isomerization of the S-DMSO trans-bonded to the 
O-DMSO can occur when it reacts with EDA, as occurs in syntheses of many DMSO-Ru ${ }^{\mathrm{II}}$-[ $\pi$-acceptor] complexes. ${ }^{13}$ It can justify the non-changing in the O-DMSO ${ }^{1} \mathrm{H}$ NMR signal. This isomerization is induced by a high $\pi$-electron competition between S-DMSO and the $\pi$-acceptor carbene ligand which is trans-positioned for some moments. It implies that the carbene ligand shows a higher trans effect than the S-DMSO, explaining the isomerization from S- to O-DMSO in the complex. Thus, it is possible to suggest that the reaction initiates with the formation of the carbene complex replacing the O-bonded DMSO, with concomitant trans-isomerization S- to O-DMSO. It is followed by coordination of the olefin from the NBE that replaces an equatorial S-DMSO. In this process, higher yield values are obtained when increasing the reaction time or in the presence of salt (Table 2; entries 1). In the latter case, the $\mathrm{O}$ atom from the equatorial S-DMSO molecule can interact with $\mathrm{NBu}_{4}{ }_{4}$ cation by an electrostatic interaction. ${ }^{19}$ This enables the axial S-DMSO ligand to leave so that the formation of the carbene complex can take place.

The ${ }^{1} \mathrm{H}$ NMR signals at 2.71 and in the range of 3.3$3.6 \mathrm{ppm}$ in the spectrum of a solution polyNBE generated in situ confirm the presence of both O- and S-DMSO molecules. Thus, both O- and S-DMSO molecules are present in the catalyst in the reaction of ROMP of NBE, working as ancillary ligands.

With these data, the reaction mechanism for the formation of the carbene-complex in the initiation process can be illustrated in Scheme 3 .

The O-DMSO substitution which provides the carbene complex can be visualized by analyzing the behavior of the fully S-bonded mono-amine derivative complexes which failed to ROMP (Table 2). Crystal data for $\mathrm{L}=\mathrm{NH}_{3}$ show an axial-amine structure trans-positioned to S-DMSO.22 This suggests a similar structure for the current complexes with one amine. For $\mathrm{L}=$ py, the better yields were only obtained at $50{ }^{\circ} \mathrm{C}$ either for 5 or $30 \mathrm{~min}$ which are the same results using the $f a c-\left[\mathrm{RuCl}_{2}(\mathrm{~S}-\mathrm{DMSO})_{3}(\mathrm{O}-\mathrm{DMSO})\right]$ complex for $5 \mathrm{~min}$ at RT. At RT, the yield with py-complex is very low. Consequently, the in situ formation of the catalyst probably occurs from the dissociation of the pyridine at $50^{\circ} \mathrm{C}$ with the formation of the carbene-complex. This is different from the O-DMSO complex, which is more labile and reacts at RT. The fact that the yield is not affected when $\mathrm{NBu}_{4} \mathrm{ClO}_{4}$ is present in the pyridine-complex solution, contrary to the case with $f a c$ - $\left[\mathrm{RuCl}_{2}(\mathrm{~S}-\mathrm{DMSO})_{3}(\mathrm{O}-\mathrm{DMSO})\right]$, confirms that the salt has no effect on the carbene-complex formation. The salt does not affect the exit of the pyridine when increasing the temperature. Thus, salt takes only the second step of the mechanism with $f a c$ - $\left[\mathrm{RuCl}_{2}(\mathrm{~S}-\mathrm{DMSO})_{3}(\mathrm{O}-\right.$ DMSO)]. It means that the carbene complex formation occurs in the absence or presence of salt. Therefore, the salt allows the second DMSO molecule to leave. A similar result suggests that the catalyst moiety complex is the same when the reaction is initiated either with the $f a c-\left[\mathrm{RuCl}_{2}(\mathrm{~S}\right.$ $\left.\mathrm{DMSO})_{3}(\mathrm{O}-\mathrm{DMSO})\right]$ or pyridine derivative complex. The higher PDI values in the experiments at $50^{\circ} \mathrm{C}$ in the absence or presence of salt can be a result of an increase in the $\mathrm{k}_{\mathrm{i}}$ relative to $\mathrm{k}_{\mathrm{p}}$, as suggested in the literature (see Table 2). ${ }^{1,20}$

The other amine complexes are also inert to the carbene complex formation and the salt does not promote the reaction. Following the interaction between the $\mathrm{NBu}_{4}{ }^{+}$<smiles>CS(C)(C)O[Ge](Cl)(S(C)(C)C)[Ge](Cl)(S(C)(C)C)S(C)(=O)=O</smiles>

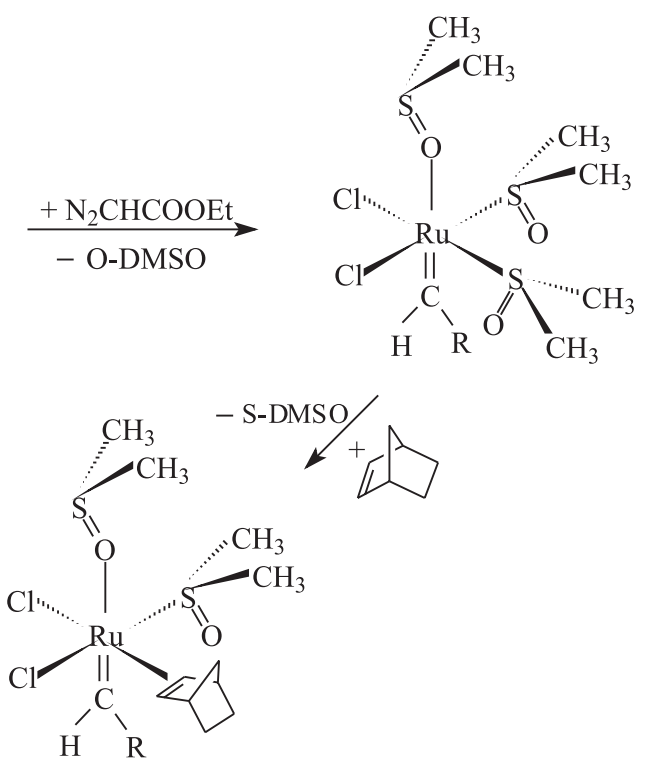


cation with the oxygen atom from S-DMSO molecule, ${ }^{19}$ it can be proposed that the $\mathrm{NBu}_{4}{ }^{+}$cations, in fact, interact with the oxygen atom of the equatorial S-DMSO molecule by electrostatic interaction. This provides a fast substitution of the axial S-bonded DMSO molecule in $f a c-\left[\mathrm{RuCl}_{2}(\mathrm{~S}-\right.$ DMSO $\left.)_{3}(\mathrm{O}-\mathrm{DMSO})\right]$ at room temperature with better yields, without affecting the PDI.

The presence of the O-DMSO molecule in the fac$\left[\mathrm{RuCl}_{2}(\mathrm{~S}-\mathrm{DMSO})_{3}(\mathrm{O}-\mathrm{DMSO})\right]$ complex and its absence in the amine type complex, when the complexes are in solution, can be observed from the FTIR experiments. The infrared spectra of the $f a c-\left[\mathrm{RuCl}_{2}(\mathrm{~S}-\mathrm{DMSO})_{3}(\mathrm{O}-\mathrm{DMSO})\right]$ complex in $\mathrm{CH}_{2} \mathrm{Cl}_{2}$ shows typical $v_{\mathrm{S}=\mathrm{O}}(\mathrm{S}-\mathrm{DMSO}), v_{\mathrm{S}=\mathrm{O}}(\mathrm{O}-\mathrm{DMSO})$, $v_{\mathrm{Ru}-\mathrm{S}}(\mathrm{S}-\mathrm{DMSO})$ and $v_{\mathrm{Ru}-\mathrm{O}}(\mathrm{O}-\mathrm{DMSO})$ bands, in agreement with those in the solid state spectra. ${ }^{12,13,16}$ In the case of the amine complexes, both $v_{\mathrm{S}=\mathrm{O}}(\mathrm{O}-\mathrm{DMSO})$ and $v_{\mathrm{Ru}-\mathrm{O}}(\mathrm{O}-\mathrm{DMSO})$ bands are not observed. It suggests that the complexes are S-DMSO types, as expected. ${ }^{13,16}$ Furthermore, they do not undergo isomerization when in solution. It can be supposed that the amines block the production of the carbene, resulting in inert complexes to ROMP.

The imidazole ligand, which is a better $\sigma$-donor than pyridine considering the $\mathrm{pK}_{\mathrm{a}}$ values, makes the complex less active than the pyridine derivative complex (Table 2; entries 11-14).

If a second amine molecule replaces another DMSO molecule, the resulting complexes are also inert to ROMP. Then, no successful reactions are obtained with complexes with two coordinated amines (Table 2; entries 15-26).

The complex with two Meim shows activity at $50{ }^{\circ} \mathrm{C}$. Perhaps this activity is associated to the hindrance of the methyl group. In the case of bzim, the complex was only soluble in $10 \% \mathrm{DMF} / \mathrm{CHCl}_{3}$ and the presence of DMF can poison the complex activity.

The $\mathrm{Cl}^{-}$ions are not discoordinated in the course of the polymerization process considering the same yield results when in the presence of $\mathrm{NaCl}$. In counterpart, the presence of $\mathrm{Cl}^{-}$ions are important for the process considering that the reaction failed to occur under specified conditions when they were substituted by triflate ion. Thus, it can be expected that the $\pi$-donor $\mathrm{Cl}^{-}$ligands also perform the role of the ancillary ligand, as known in the literature. ${ }^{23}$

The best activity of the pyridine derivative at $50{ }^{\circ} \mathrm{C}$ for either 5 or $30 \mathrm{~min}$ can be attributed to temperature dependence where the salt can take the second reaction step.

\section{Conclusions}

The $f a c-\left[\mathrm{RuCl}_{2}(\mathrm{~S}-\mathrm{DMSO})_{3}(\mathrm{O}-\mathrm{DMSO})\right]$ complex behaves as a precatalyst for the ROMP of NBE in mild conditions, with $\left\{\mathrm{RuCl}_{2}(\mathrm{~S}-\mathrm{DMSO})(\mathrm{O}-\mathrm{DMSO})\right\}$ a moiety complex as the active species. Both O- and S-DMSO molecules provide ancillary effects for this catalytic process. The presence of an $\mathrm{N}$-heterocyclic inhibits the production of the active catalytic species due to its interaction with the $\mathrm{Ru}^{\mathrm{II}}$ metal center which makes the formation of the carbene complex difficult. This is contrary to many amine-phosphine $\mathrm{Ru}^{\mathrm{II}}$ complexes where the presence of amines enhanced the reactivity in relation to the pure phosphine complexes. ${ }^{10}$ The system with fac$\left[\mathrm{RuCl}_{2}(\mathrm{~S}-\mathrm{DMSO})_{3}(\mathrm{O}-\mathrm{DMSO})\right]$ is versatile, as it does not require operating conditions with extreme absence of humidity and $\mathrm{O}_{2}$.

\section{Acknowledgments}

The authors would like to thank FAPESP (process numbers 2000/11443-0 and 2006/57577-4), CAPES and CNPq for their financial support and fellowships. S. A. A. S. (Universidade Federal do Maranhão, São Luiz, Brazil) was a CAPES/PICDT fellow at IQSC-USP.

\section{Supplementary Information}

Supplementary data are available free of charge at http://jbcs.sbq.org.br, as PDF file.

\section{References}

1. Grubbs, R. H.; Tetrahedron 2004, 60, 7117; Bielawski, C. W.; Grubbs, R. H.; Prog. Polym. Sci. 2007, 32, 1.

2. Frenzel, U.; Nuyken, O.; J. Polym. Sci. Part A: Polym. Chem. 2002, 60, 2895.

3. Dragutan, I; Dragutan, V; Delaude, L; Demonceau, A; Noels, A.; Rev. Roum. Chim. 2007, 52, 1013.

4. Garcia-Álvarez, J. L.; Curr. Org. Chem. 2008, 12, 1199; Sledz, P; Mauduit, M.; Grela, K.; Chem. Soc. Rev. 2008, 37, 2433; Rybak, A.; Patrice, A. F.; Meier, M. A. R.; Eur. J. Lipid Sci. Technol. 2008, 110, 797; Zaman, S.; Curnow, O. J.; Abell, A. D.; Aust. J. Chem. 2009, 62, 91; Butscher, D.; Grela, K.; Angew. Chem., Int. Ed. 2009, 48, 442.

5. Binder, J. B.; Raines, R. T.; Curr. Opin. Chem. Biol. 2008, 12, 767; Colombo, M.; Peretto; Drug Discov. Today 2008, 13, 677; Bucmeiser, M. R.; Chem. Rev. 2009, 109, 303;

6. Chauvin, Y.; Angew. Chem., Int. Ed. 2006, 45, 3747; Schrock, R. R.; Angew. Chem., Int. Ed. 2006, 45, 3759; Grubbs, R. H.; Angew. Chem., Int. Ed. 2006, 45, 3765.

7. Hoveyda, A. H.; Gillinghan, D. G.; Veldhuizen, J. J. V.; Kataoka, O.; Garber, A. B.; Kingsbury, J. S.; Harrity, J. P. A.; Org. Biomol. Chem. 2004, 2, 8 .

8. Mothes, E.; Sentets, S.; Luquin, M. A.; Mathieu, R.; Lugan, N.; Lavigne, G.; Organometallics 2008, 27, 1193. 
9. Mol, J. C.; J. Mol. Catal. A: Chem. 2004, 213, 39; Streck R.; J. Mol. Catal. 1992, 76, 359.

10. Matos, J. M. E.; Lima-Neto, B. S.; J. Mol. Catal. A: Chem. 2005, 240, 233; Matos, J. M. E.; Lima-Neto, B. S.; J. Mol. Catal. A: Chem. 2004, 222, 81; Matos, J. M. E.; Lima-Neto, B. S.; Catal. Today 2005, 107-108, 282; Matos, J. M. E.; Lima-Neto, B. S.; J. Mol. Catal. A: Chem. 2006, 259, 286; Sá, J. L. S.; Lima-Neto, B. S.; J. Mol. Catal. A: Chem. 2009, 304,187.

11. James, B. R.; Ochiai, E.; Rampel, G. L.; Inorg. Nucl. Chem. Lett. 1971, 7, 781 .

12. Evans, I. P.; Spencer, A.; Wilkinson, G.; J. Chem. Soc., Dalton Trans. 1973, 204.

13. Calligaris, M.; Carugo, O.; Coord. Chem. Rev. 1996, 153, 83; Calligaris, M.; Coord. Chem. Rev. 2004, 248, 351; Stener, M.; Calligaris, M.; THEOCHEM 2000, 497, 91; Davies, J. A.; Adv. Inorg. Chem. Radiochem. 1981, 24, 115; Bora, T.; Singh, M. M.; J. Inorg. Nucl. Chem. 1976, 38, 1815; Serli, B.; Zangrando, E.; Gianferrara,T.; Yellowlees, L.; Alessio, E.; Coord. Chem. Rev. 2003, 245, 73.

14. Fontal, B.; Anzelotti, A.; Reyes, M.; Bellandi, F.; Suarez, T.; Catal. Lett. 1999, 59, 187.

15. Abdallaoui, I. A.; Sémeril, D.; Dixneuf, P. H.; J. Mol. Catal. A: Chem. 2002, 182, 577.

16. Alessio, E.; Calligaris, M.; Iwamoto, M.; Marzilli, L. G.; Inorg. Chem. 1996, 35, 2538; Henn, M.; Alessio, E.; Mestroni, G.; Calligaris, M.; Attia, W. M.; Inorg. Chim. Acta 1991, 187, 39.
17. Herrmann, W. A.; Schattenmann, W. C.; Nuyken, O.; Glander, S. C.; Angew. Chem., Int. Ed. 1996, 35, 1087.

18. Conrad, J. C.; Amoroso, D.; Czechura, P.; Yap, G. P. A.; Fogg, D. E.; Organometallics 2003, 22, 3634.

19. Jaswal, J. S.; Yapp, D. T. T.; Rettig, S. J.; James, B. R.; Skov, K. A.; J. Chem. Soc., Chem. Commun. 1992, 1528; Jaswal, J. S.; Yapp, D. T. T.; Rettig, S. J.; James, B. R.; Skov, K. A.; Inorg. Chim. Acta 1993, 207, 97; Magnera, T. F.; Caldwell, G.; Sunner, J.; Ikuta, S.; Kebarle, P.; J. Am. Chem. Soc. 1984, 106, 6140.

20. Ivin, K. J.; Mol, J. C.; Olefin Metathesis and Metathesis Polymerization, Academic Press: San Diego, 1997.

21. Fotheringham, J. D.; Heath, G. A.; Lindsay, A. J.; Stephenson, T. A.; J. Chem. Res. (S) 1986, 82; Fotheringham, J. D.; Heath, G. A.; Lindsay, A. J.; Stephenson, T. A.; J. Chem. Res. (M) 1986, 801; Barnes, J. R.; Goodfellow, R. J.; J. Chem. Res. (S) 1979, 350; Barnes, J. R.; Goodfellow, R. J.; J. Chem. Res. (M) 1979, 4301;

22. Alessio, E.; Iengo, E.; Geremia, S.; Calligaris, M.; Inorg. Chim. Acta 2003, 344, 183.

23. Dias, E. L.; Nguyen, T.; Grubbs, R. H.; J. Am. Chem. Soc. 1997, $119,3887$.

Received: July 16, 2009

Web Release Date: November 19, 2009

FAPESP helped in meeting the publication costs of this article. 


\title{
DMSO Molecule as Ancillary Ligand in Ru-Based Catalysts for Ring Opening Metathesis Polymerization
}

\author{
Sirlane A. A. Santana, Valdemiro P. Carvalho Jr. and Benedito S. Lima-Neto* \\ Instituto de Química de São Carlos, Universidade de São Paulo, \\ CP 780, 13560-970 São Carlos-SP, Brazil
}

\section{Syntheses of the Complexes}

\section{$\mathrm{fac}\left[\mathrm{RuCl} \mathrm{Cl}_{2}(\mathrm{~S}-\mathrm{DMSO})_{3}(\mathrm{O}-\mathrm{DMSO})\right](\boldsymbol{I})$}

Following Evans, I. P.; Spencer, A.; Wilkinson, G.; J. Chem. Soc. Dalton, 1973, 2, 204: $800 \mathrm{mg}$ of $\mathrm{RuCl}_{3} \cdot 3 \mathrm{H}_{2} \mathrm{O}$ (3.0 mmol) was dissolved in $5 \mathrm{~mL}$ of DMSO. The solution was refluxed for $5 \mathrm{~min}$ and then the solvent was reduced to c.a. $2.5 \mathrm{~mL}$. $20 \mathrm{~mL}$ of acetone were added at room temperature. A yellow precipitate was filtered and washed with iced acetone and diethyl ether. Dried in a vacuum. Yield: $92 \%$.

\section{$\mathrm{fac}\left[\mathrm{RuCl}_{2}(\mathrm{~S}-\mathrm{DMSO})_{3}(\mathrm{py})\right]$}

Following Alessio, E.; Calligaris, M.; Iwamoto, M.; Marzilli, L. G.; Inorg. Chem. 1996, 35, 2538: $80 \mu \mathrm{L}$ of pyridine (1 mmol) was added to a solution of $250 \mathrm{mg}$ of $\mathbf{I}$ $(0.5 \mathrm{mmol})$ in $10 \mathrm{~mL}$ of methanol. The mixture was stirred for $45 \mathrm{~min}$ at room temperature. A yellow precipitate was filtered and washed with iced methanol and diethyl ether. Dried in a vacuum. Yield: $80 \%$.

\section{$\mathrm{fac}^{-}\left[\mathrm{RuCl}_{2}(\mathrm{~S}-\mathrm{DMSO})_{3}(\mathrm{im})\right]$}

Following Henn, M.; Alessio, E.; Mestroni, G. Calligaris, M.; Attia, W. M.; Inorg. Chem. 1981, 187, 39: $150 \mathrm{mg}$ of imidazole (2.2 mmols) was added to a solution of $500 \mathrm{mg}$ ( $1 \mathrm{mmol})$ of I in methanol $(20 \mathrm{~mL})$. The mixture was stirred for 8 hours at room temperature. A yellow precipitate was filtered, washed with iced methanol and diethyl ether. Dried in a vacuum. Yield: $40 \%$.
cis-cis-cis-[RuCl$\left.{ }_{2}(\mathrm{~S}-\mathrm{DMSO})_{2}(\mathrm{im})_{2}\right]$

Following Henn, M.; Alessio, E.; Mestroni, G. Calligaris, M.; Attia, W. M.; Inorg. Chem. 1981, 187, 39: $500 \mathrm{mg}$ of $\mathbf{I}(1 \mathrm{mmol})$ and $150 \mathrm{mg}$ of imidazole $(2.2$ mmols) in $20 \mathrm{~mL}$ of methanol were refluxed for 6 hours. A yellow compound was filtered at room temperature, washed with iced methanol and diethyl ether. Dried in a vacuum. Yield: $63 \%$.

cis- cis-cis-[RuCl$\left(\mathrm{R}_{2}(\mathrm{D}-\mathrm{DMSO})_{2}(2-\mathrm{Meim})_{2}\right]$

Following Henn, M.; Alessio, E.; Mestroni, G. Calligaris, M.; Attia, W. M.; Inorg. Chem. 1981, 187, 39: $250 \mathrm{mg}$ of $\mathbf{I}(0.5 \mathrm{mmol})$ were dissolved in methanol $(20 \mathrm{~mL})$ and refluxed for 3 hours in presence of $90 \mathrm{mg}$ of 2-methyl-imidazole $(1.1 \mathrm{mmol})$. The orange precipitate was filtered, washed with iced acetone and diethyl ether. Dried in a vacuum. Yield: $30 \%$.

cis- cis-cis- $\left[\mathrm{RuCl}_{2}(\mathrm{~S}-\mathrm{DMSO})_{2}(\text { bzim })_{2}\right]$

Following Henn, M.; Alessio, E.; Mestroni, G. Calligaris, M.; Attia, W. M.; Inorg. Chem. 1981, 187, 39: $500 \mathrm{mg}$ of $\mathbf{I}(1 \mathrm{mmol})$ were dissolved in $\mathrm{CH}_{2} \mathrm{Cl}_{2}(20 \mathrm{~mL})$ and refluxed for 2 hours in presence of $260 \mathrm{mg}$ of benzimidazole ( $2.2 \mathrm{mmol}$ ). The solvent was reduced to $c a .5 \mathrm{~mL}$ and then $20 \mathrm{~mL}$ of diethyl ether were added at room temperature. A yellow precipitate was filtered, washed with iced diethyl ether. Dried in a vacuum. Yield: $68 \%$.

*e-mail: benedito@iqsc.usp.br 


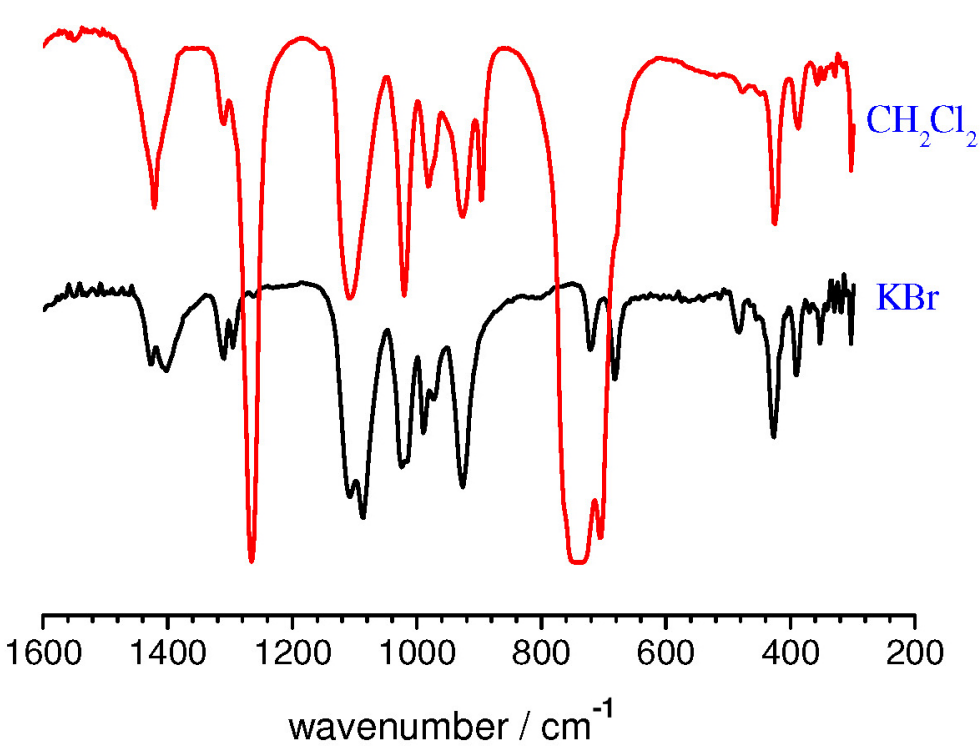

Figure S1. FTIR spectra of $f a c$ - $\left[\mathrm{RuCl}_{2}(\mathrm{~S}-\mathrm{DMSO})_{3}(\mathrm{O}-\mathrm{DMSO})\right]$ in $\mathrm{KBr}(1: 100)$ and $\mathrm{CH}_{2} \mathrm{Cl}_{2}$.

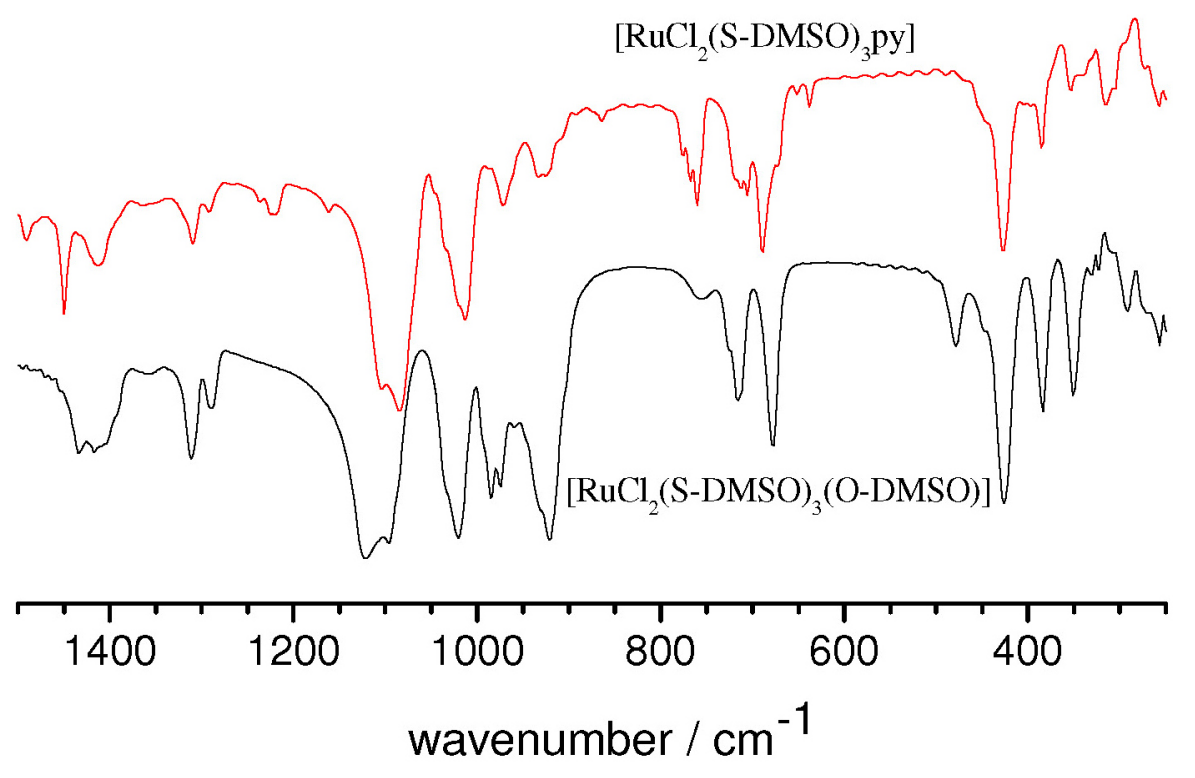

Figure S2. FTIR spectra in $\mathrm{KBr}(1: 100)$ of $f a c-\left[\mathrm{RuCl}_{2}(\mathrm{~S}-\mathrm{DMSO})_{3}(\mathrm{O}-\mathrm{DMSO})\right]$ and $f a c-\left[\mathrm{RuCl}_{2}(\mathrm{~S}-\mathrm{DMSO})_{3}(\mathrm{py})\right]$. 


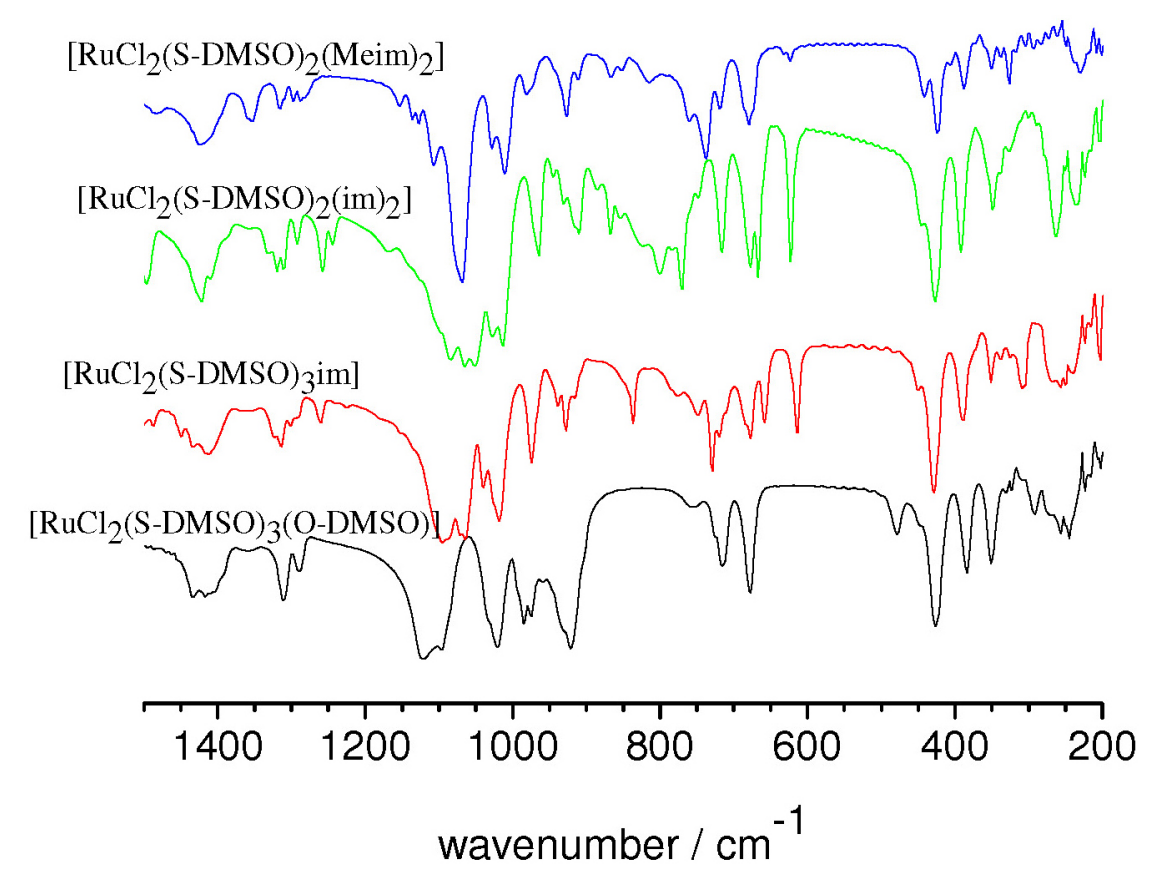

Figure S3. FTIR spectra in $\mathrm{KBr}(1: 100)$ of fac -[ $\left.\mathrm{RuCl}_{2}(\mathrm{~S}-\mathrm{DMSO})_{3}(\mathrm{O}-\mathrm{DMSO})\right]$, cis-[ $\left.\mathrm{RuCl}_{2}(\mathrm{~S}-\mathrm{DMSO})_{3}(\mathrm{im})\right]$, cis-cis-cis-[ $\left.\mathrm{RuCl}_{2}(\mathrm{~S}-\mathrm{DMSO})_{2}(\mathrm{im})_{2}\right]$, cis-ciscis-[RuCl$\left.{ }_{2}(\mathrm{~S}-\mathrm{DMSO})_{2}(2-\mathrm{Meim})_{2}\right]$.

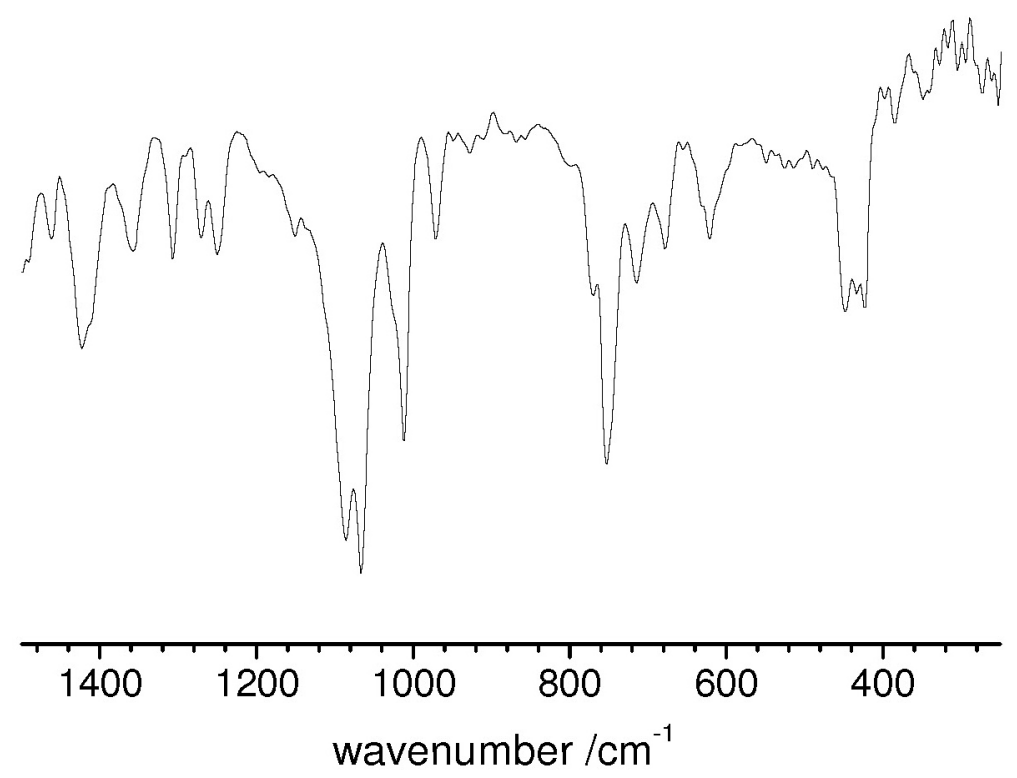

Figure S4. FTIR spectra in $\mathrm{KBr}(1: 100)$ of cis-cis-cis-[ $\left[\mathrm{RuCl}_{2}(\mathrm{~S}-\mathrm{DMSO})_{2}(\mathrm{bzim})_{2}\right]$. 


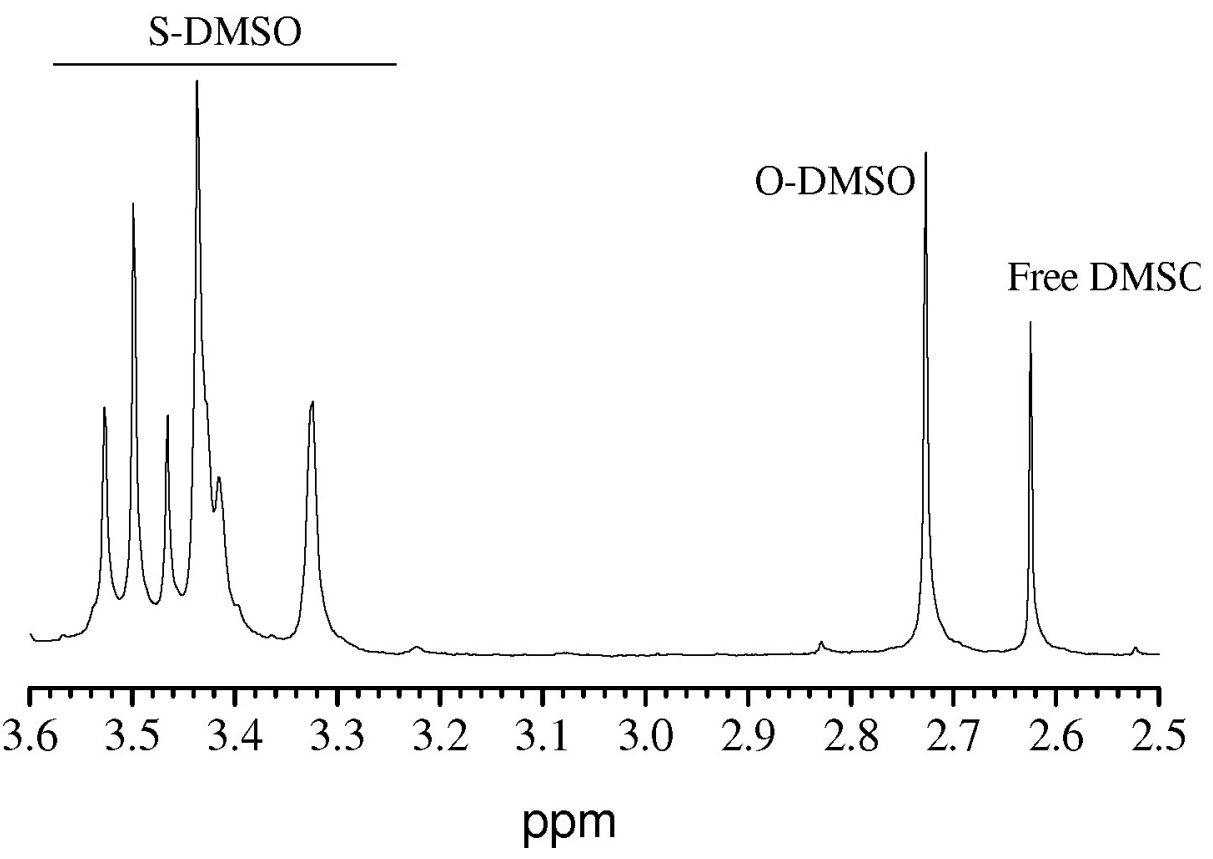

Figure S5. ${ }^{~} \mathrm{H}-\mathrm{NMR}$ spectrum of $f a c-\left[\mathrm{RuCl}_{2}(\mathrm{~S}-\mathrm{DMSO})_{3}(\mathrm{O}-\mathrm{DMSO})\right]$ in $\mathrm{CDCl}_{3}$.

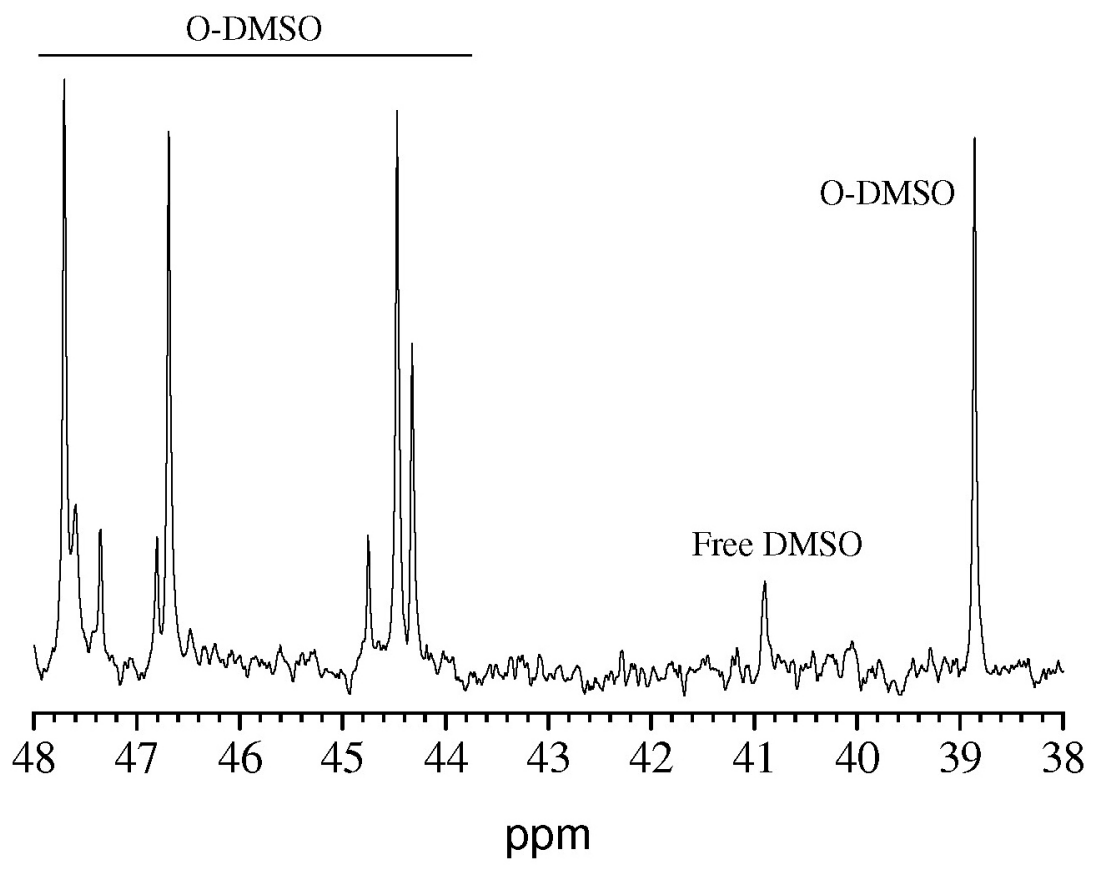

Figure S6. ${ }^{13} \mathrm{C}-\mathrm{NMR}$ spectrum of $\mathrm{fac}-\left[\mathrm{RuCl}_{2}(\mathrm{~S}-\mathrm{DMSO})_{3}(\mathrm{O}-\mathrm{DMSO})\right]$ in $\mathrm{CDCl}_{3}$. 


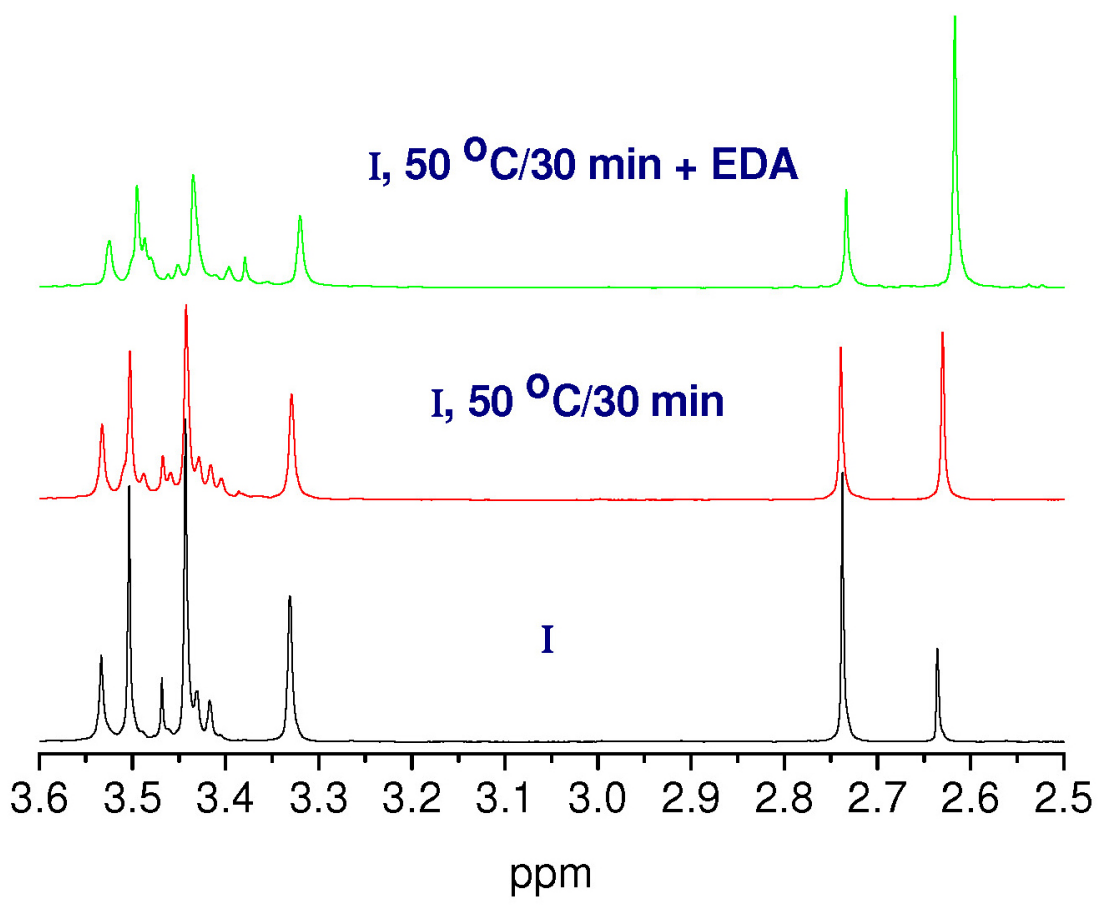

Figure S7. ${ }^{1} \mathrm{H}-\mathrm{NMR}$ spectra of $f a c-\left[\mathrm{RuCl}_{2}(\mathrm{~S}-\mathrm{DMSO})_{3}(\mathrm{O}-\mathrm{DMSO})\right]$, I, in absence or presence od EDA at different temperature, in $\mathrm{CDCl}{ }_{3}$.

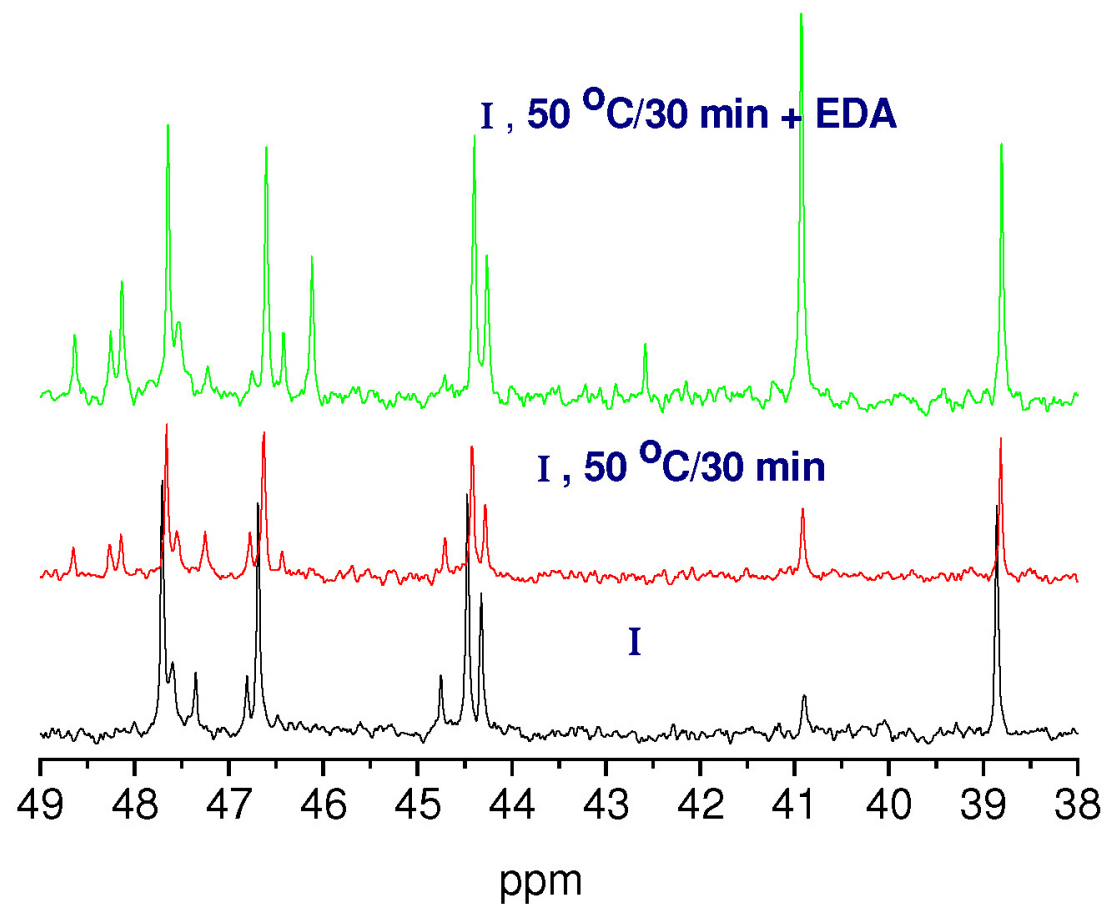

Figure S8. ${ }^{13} \mathrm{C}-\mathrm{NMR}$ spectra of $f a c-\left[\mathrm{RuCl}_{2}(\mathrm{~S}-\mathrm{DMSO})_{3}(\mathrm{O}-\mathrm{DMSO})\right], \mathbf{I}$, in absence or presence of EDA at different temperature, in $\mathrm{CDCl}_{3}$. 


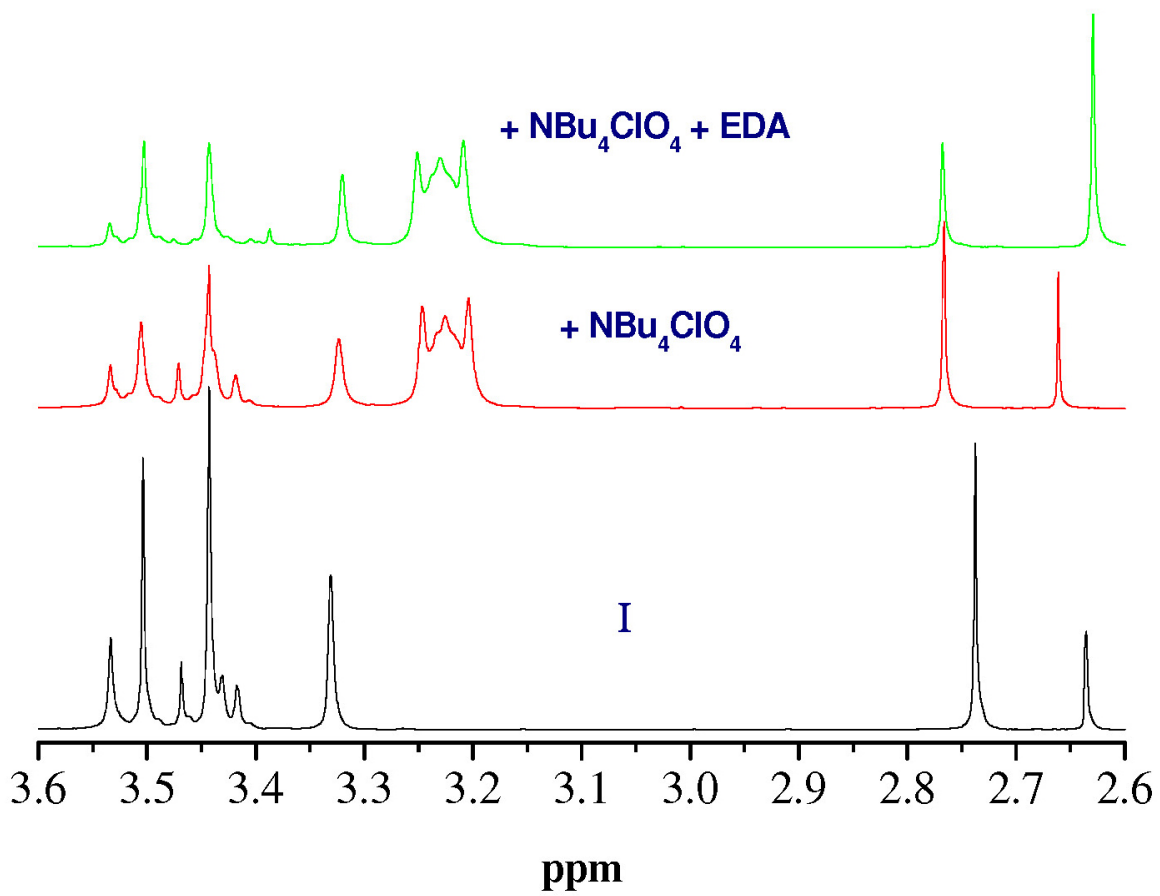

Figure S9. ${ }^{1} \mathrm{H}-\mathrm{NMR}$ spectra of $f a c-\left[\mathrm{RuCl}_{2}(\mathrm{~S}-\mathrm{DMSO})_{3}(\mathrm{O}-\mathrm{DMSO})\right]$, $\mathbf{I}$, in presence of $\mathrm{NBu}_{4} \mathrm{ClO}_{4}$ and $\mathrm{EDA}$, in $\mathrm{CDCl}_{3}$.

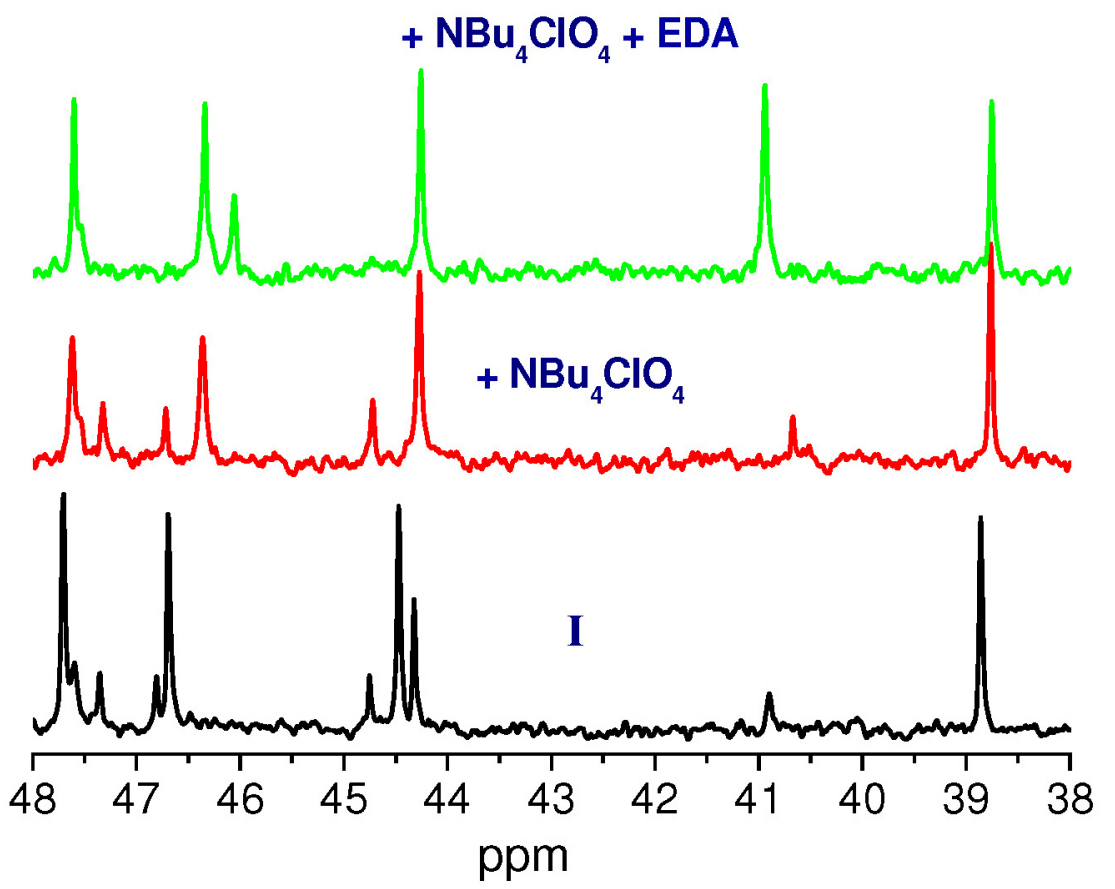

Figure S10. ${ }^{13} \mathrm{C}-\mathrm{NMR}$ spectra of $f a c-\left[\mathrm{RuCl}_{2}(\mathrm{~S}-\mathrm{DMSO})_{3}(\mathrm{O}-\mathrm{DMSO})\right]$, $\mathbf{I}$, in presence of $\mathrm{NBu}_{4} \mathrm{ClO}_{4}$ and $\mathrm{EDA}$, in $\mathrm{CDCl}_{3}$. 